\title{
SISTEM PREDIKSI PERSEDIAAN STOK DARAH DENGAN METODE LEAST SQUARE PADA UNIT TRANSFUSI DARAH STUDI KASUS PMI KOTA CIREBON
}

\author{
Muhammad Hatta ${ }^{1}$, Alfi Fauziah Fitri ${ }^{2}$ \\ ${ }^{1,2}$ Sistem Informasi, Universitas Catur Insan Cendekia, Cirebon \\ 1'muhammad.hatta@cic.ac.id, 2alfifauziah51@gmail.com
}

\begin{abstract}
ABSTRAK
Unit Transfusi darah (UTD) sebagai penyedia pasokan darah diperlukan untuk memenuhi permintaan darah, namun dalam kenyataannya, stok darah tidak selalu memenuhi permintaan darah. Jumlah stok golongan darah di UTD tergantung pada donor darah yang secara sukarela mendonorkan darah. Sel darah merah hanya memiliki rentang hidup 35 hari sejak mereka disumbangkan, jika mereka telah melewati waktu itu darah tidak dapat digunakan untuk transfusi. Faktor atau parameter yang mempengaruhi jumlah produk darah menuntut, yaitu lingkungan, wabah penyakit dan perbedaan daya tahan tubuh masing-masing golongan darah. Selain itu, jenisjenis produk darah juga memiliki sejumlah permintaan berbeda tergantung pada tingkat kebutuhan darah untuk kesehatan. Sehingga perlu sebuah sistem prediksi persediaan stok obat untuk periode berikutnya, dalam prediksi menggunakan adalah metode Least Square. Hasil dari penelitian ini adalah sistem informasi prediksi kebutuhan stok daraah untuk periode berikunya sehingga memudahkan petugas dalam mengelola data-data serta data laporan permintaan darah dan stok darah per periode.
\end{abstract}

Kata Kunci- Metode Least Square, Sistem Prediksi, Persediaan Stok Darah, PMI.

\begin{abstract}
Blood Transfusion Unit (UTD) as a blood supply provider is needed to meet blood demand, but in reality, blood stock does not always meet blood demand. The number of blood type stocks in UTD depends on blood donors who voluntarily donate blood. Red blood cells only have a life span of 35 days since they are donated, if they have passed that time the blood cannot be used for transfusions. Factors or parameters that affect the amount of blood products demanded, namely the environment, disease outbreaks and differences in endurance of each blood type. In addition, the types of blood products also have a number of different requests depending on the level of blood needs for health. So we need a prediction system for drug stock inventory for the next period, the prediction using is Least Square method. The results of this study are predictive information systems for blood stock requirements for the next period, making it easier for officers to manage data and report data on blood demand and blood stock per period.
\end{abstract}

Keywords—Method of Square Square, Prediction System, Stock of Blood Stock, PMI. 


\section{PENDAHULUAN}

Darah menjadi kebutuhan yang setiap hari harus dipenuhi oleh beberapa rumah sakit di setiap daerah. Kebutuhan darah yang cukup besar, terkadang tidak bisa dipenuhi oleh Palang Merah Indonesia (PMI) pada waktu tertentu. PMI akan melakukan berbagai upaya untuk menjaga stok darah, berdasarkan hasil wawancara dengan bagian IT, setiap harinya PMI menyatakan bahwa permintaan darah di Kota Cirebon setiap tahunnya kurang lebih sebanyak 25.000 kantong darah pada tahun 2018 dan 28.000 kantong darah pada tahun 2019.

Departemen kesehatan membentuk Palang Merah Indonesia (PMI) sebagai salah satu organisasi untuk mengantisipasi kebutuhan darah yang bertugas menyediakan darah yang layak untuk digunakan, proses penyampaian informasi terkait donor darah, masyarakat harus selalu mendatangi PMI, sehingga kurang efisien dan efektif. Selain itu belum adanya sistem informasi untuk prediksi stok darah untuk antisipasi persediaan darah yang dibutuhkan pada periode selanjutnya.

Pemenuhan ketersediaan darah merupakan suatu hal yang sangat penting. Stok darah yang terlalu menumpuk akan mengakibatkan kerugian yang tidak sedikit misalnya darah banyak yang terbuang karena darah memiliki masa kadaluarsa. Sebaliknya, jika stok darah terlalu sedikit akan menyebabkan tidak terpenuhinya kebutuhan darah untuk masyarakat.

Metode yang dipilih dalam penelitian dalam prediksi kebutuhan stok darah adalah metode Least Square sebagai dasar peramalan. Least Square merupakan cara yang lebih umum dan lebih baik untuk menentukan trend dibandingkan dengan metode-metode lain. Hal ini akan memudahkan bagian PMI untuk mengantisipasi kekurangan persediaan stok darah pada periode selanjutnya.

Berdasarkan uraian latar belakang diatas, maka penulis memilih topik "Penerapan Metode Least Square untuk Prediksi Persediaan Stok Darah pada PMI Kota Cirebon.". Selanjutnya laporan akan disampaikan dalam bentuk skripsi pada program studi Sistem Informasi.

\subsection{Identifikasi Masalah}

Identifikasi permasalahan dalam penelitian berkaitan persedian stok darah PMI Kota Cirebon ini yaitu:

1. Belum adanya sistem untuk memprediksi persediaan stok darah pada PMI Kota Cirebon.

2. Bagaimana memprediksi stok darah pada bulan yang akan datang di PMI Kota Cirebon menggunakan metode Least Square berdasarkan data distribusi bulan-bulan sebelumnya.

3. Bagaimana merancang dan membuat sistem peramalan stok darah pada PMI menggunakan metode Least Square.

\subsection{Batasan Masalah}

Batasan masalah dalam penelitian prediksi persediaan stok darah PMI Kota Cirebon ini yaitu:
1. Aplikasi ini hanya sampai pada laporan data pendonor, laporan stok darah, laporan pemesanan darah, laporan periode per golongan darah dan perhitungan forecast darah. Hal ini bertujuan agar dapat diketahui alur perhitungan yang lebih lengkap dalam menyajikan informasi persediaan darah bagi pihak terkait sebagai suatu dasar pengambilan keputusan.

2. Sistem ini dirancang menggunakan metode Least Square berdasarkan data mining dan data distribusi darah dari tahun 2019.

3. Data mining yang digunakan yaitu forecasting dengan metode Least Square.

\section{TINJAUAN PUSTAKA}

\subsection{Data Maining}

Menurut Kusrini dan Emha Taufiq Luthfi, Algoritma Data Mining, 2009. Data mining adalah suatu istilah yang digunakan untuk menemukan pengetahuan yang tersembunyi di dalam database. Data mining merupakan proses semi otomatik yang menggunakan teknik statistik, matematika, kecerdasan buatan, dan machine learning untuk mengekstraksi dan mengidentifikasi informasi pengetahuan potensial dan berguna yang bermanfaat yang tersimpan di dalam database besar.

\subsection{Peramalan (Forecasting)}

Peramalan pada dasarnya merupakan perkiraan suatu peristiwa di masa mendatang. Dimana situasi peramalan sangat beragam dalam horison waktu peramalan, faktor yang menentukan hasil sebenarnya, tipe pola data dan berbagai aspek lainnya. Sebelum melakukan peramalan harus diketahui terlebih dahulu apa sebenarnya persoalan dalam pengambilan keputusan itu. Peramalan adalah pemikiran terhadap suatu besaran, misalnya untuk menentukan jumlah penjualan barang pada periode yang akan datang. Pada hakekatnya peramalan hanya merupakan suatu perkiraan (guess) dengan menggunakan teknik-teknik tertentu, maka peramalan menjadi lebih sekedar perkiraan. Peramalan dapat dikatakan perkiraan yang ilmiah (educated guess). Setiap pengambilan keputusan yang menyangkut keadaan di masa yang akan datang, maka pasti ada peramalan yang melandasi pengambilan keputusan. Tujuan peramalan adalah untuk meredam ketidakpastian, sehingga diperoleh suatu perkiraan yang mendekati keadaan yang sebenarnya. Jika hasil peramalan mendekati akurat, maka hal ini sangat berpengaruh besar untuk proses pengambilan keputusan pada perusahaan.

\section{a. Model Trend Linier}

Trend Linear memiliki persamaan yang secara umum dapat dinyatakan sebagai berikut :

$$
Y=a+b X(1)
$$

Keterangan :

$\mathrm{Y}$ : data berkala (time series)

$\mathrm{X}$ : periode waktu 
Jurnal Ilmiah Ilmu Komputer Vol. 5, No. 1, April 2019

Fakultas Ilmu Komputer

Universitas AL Asyariah Mandar

a : nilai trend pada tahun dasar.

b : rata-rata pertumbuhan nilai trend tiap tahun.

\section{b. Metode Least Square}

Menurut Fajar, Metode Least Square untuk Prediksi Penjualan Sari Kedelai Rosi, 2016. Metode Least Square merupakan salah satu metode berupa data deret berkala atau time series, yang mana dibutuhkan data-data permintaan dimasa lampau untuk melakukan peramalan permintaan dimasa mendatang sehingga dapat ditentukan hasilnya. Metode Least Square ini termasuk dalam golongan metode pendekatan berdasarkan distribusi error yang terukur melalui interval pendekatan secara keseluruhan.

Proses prediksi dengan metode metode least square dapat dijelaskan melalui sebagai berikut :

1. Menginisialisasi data masukan.

2. Menentukan periode data/ variabel waktu.

3. Menghitung jumlah pemakaian (Y).

4. Menghitung skor $\mathrm{x}$.

5. Mencari nilai koefisien menggunakan $a=\sum \frac{Y}{n}$

6. Menghitung nilai koefisien terhadap $\mathrm{x}($ waktu) menggunakan

$b=\sum \frac{X Y}{X 2}$

7. Menentukan persamaan variabel nilai trend dengan $Y^{\prime}=a+b x$

\subsection{Persedian Darah}

Pengertian Darah berasal dari bahasa yunani yakni hemo, hemato dan haima yang berarti darah.Darah adalah cairan yang terdapat pada semua makhluk hidup (kecuali tumbuhan) tingkat tinggi yang berfungsi mengirimkan zatzat dan oksigen yang dibutuhkan oleh jaringan tubuh, mengangkut bahan-bahan kimia hasil metabolisme, dan juga berfungsi sebagai pertahanan tubuh manusia terhadap virus atau bakteri [3].

Ada dua teknik yang dipakai untuk mengelompokkan darah, yaitu menggunakan sistem $\mathrm{ABO}$ dan rhesus (Rh). Kedua sistem ini bisa sangat membantu jika Anda ingin melakukan transfusi darah [1]

Melalui sistem $\mathrm{ABO}$, golongan darah dibagi menjadi 4 tipe, yaitu A, B, AB dan $\mathrm{O}$.

a. Jika Anda memiliki golongan darah A, maka Anda memiliki antigen A pada sel darah merah dan memproduksi antibodi untuk melawan sel darah merah dengan antigen.

b. Jika Anda memiliki golongan darah B, maka Anda memiliki antigen B pada sel darah merah dan memproduksi antibodi A untuk melawan sel darah merah dengan antigen $\mathrm{A}$. c. Jika Anda memiliki golongan darah AB, maka Anda memiliki antigen A dan B pada sel darah merah. Ini juga berarti Anda tidak memiliki antibodi A dan B pada plasma darah.

d. Jika Anda memiliki golongan darah O, maka Anda tidak memiliki antigen A atau B pada sel darah merah. Orang bergolongan darah $\mathrm{O}$ memproduksi antibodi A dan B di plasma darah.

\section{METODOLOGI}

\subsection{Diagram Sistem Prediksi Metode Least Square}

Diagram alir sistem prediksi dengan metode Least Square ditunjukkan pada

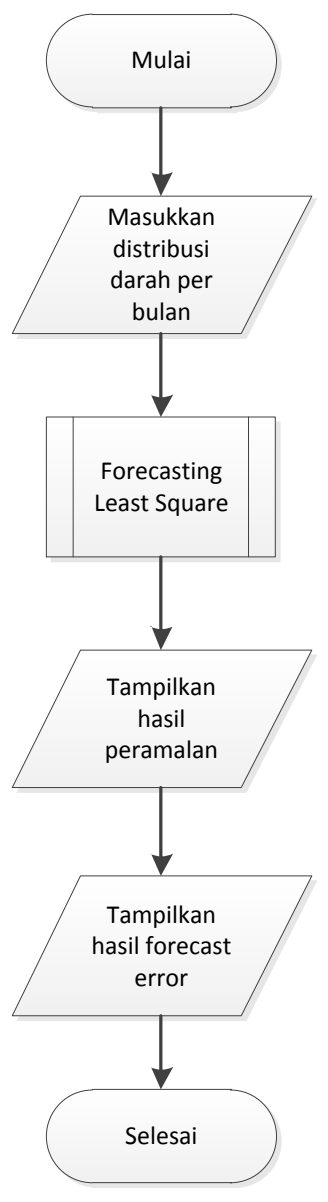

Gambar 1. Diagram Alir Metode Least Square

Diagram Alir Metode Least Square menjelaskan tahap analisis dimulai dengan memasukkan distribusi darah per bulan. Kemudian sistem akan memulai peramalan distribusi periode berikutnya menggunakan metode Least Square (Kuadrat Terkecil). Setelah proses peramalan selesai maka sistem akan menampilkan hasil peramalan untuk periode berikutnya.

\subsection{Flowmap yang Berjalan}


Jurnal Ilmiah Ilmu Komputer Vol. 5, No. 1, April 2019

Fakultas Ilmu Komputer

Universitas AL Asyariah Mandar

Berikut ini adalah Flowmap untuk proses informasi persediaan darah yang saat ini digunakan PMI Kota Cirebon :

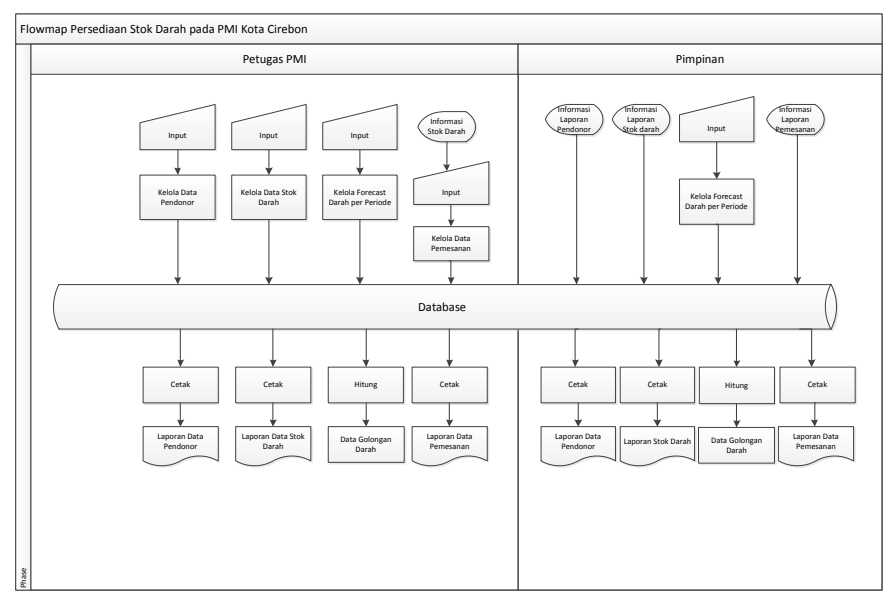

Gambar 2. Flowchart yang Berjalan

\subsection{Flowmap Komputerisasi Usulan}

Dalam aplikasi berbasis web ini terdapat dua entitas yaitu User dan Petugas. Berikut adalah penjelasan flowmap Usulan untuk Petugas dan Pimpinan:

a. Bagian Petugas PMI menginput data pendonor, data stok darah, forecast darah dan data pemesanan darah ke dalam sistem kemudian sistem mencetak laporan data pendonor, laporan data stok darah,dan laporan data pemesanan darah.

b. Bagian Pimpinan hanya dapat melihat laporan data pendonor, laporan data stok darah, laporan forecast darah dan laporan data pemesanan darah.

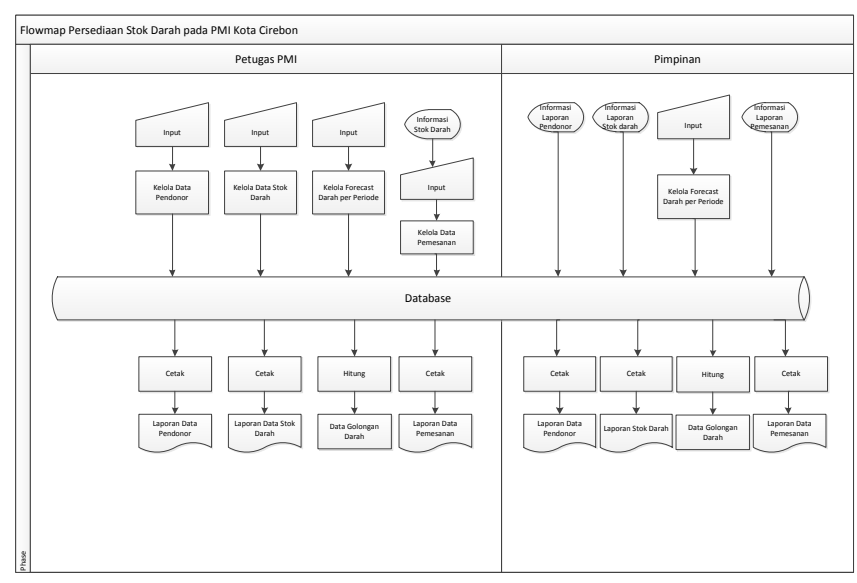

Gambar 3. Flowmap Usulan

\subsection{Diagram Konteks}

Berikut ini adalah rancangan diagram konteks untuk beserta penjelasannya :
(P) ISSN 2442-451X

(O) ISSN 2503-3832

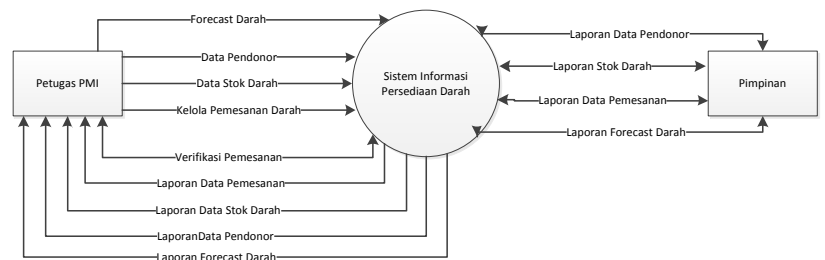

Gambar 4. Diagram Konteks

\section{HASIL PENELITIAN (Times New 10 Bold)}

Hasil dan diskusi dinyatakan dalam kerangka kerja ilmiah yang solid dan jelas yang diperoleh, bukan deretan tabel data atau gambar.

Dalam implementasi program dapat dilihat bentuk tampilan jalannya aplikasi baik input maupun output. Adapun implementasi aplikasi terbagi menjadi 2 yaitu implementasi aplikasi untuk Petugas dan implementasi program untuk Pimpinan.

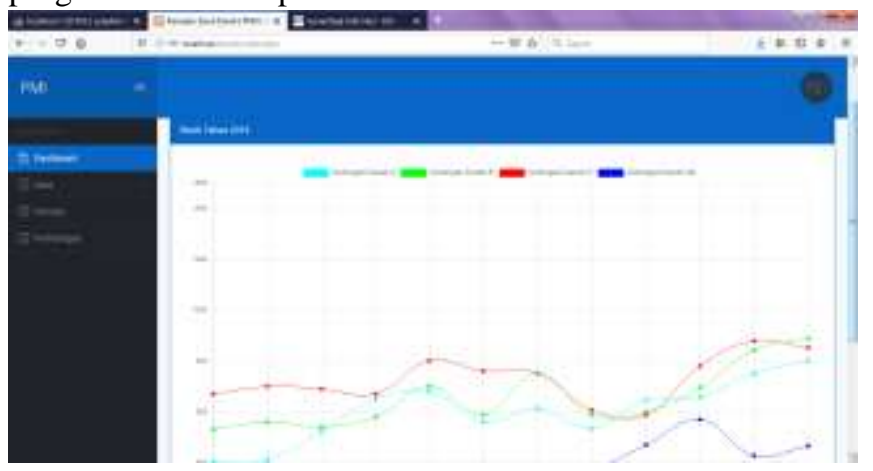

Gambar 5. Tampilan Dashboard Petugas

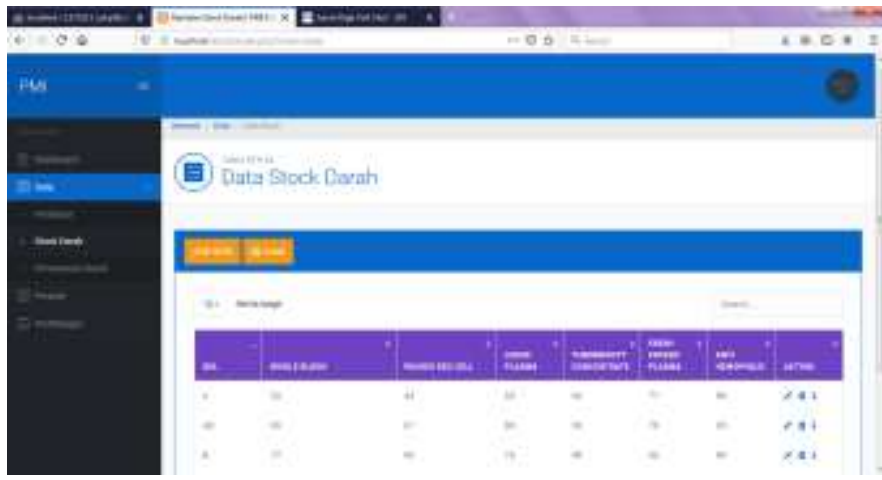

Gambar 6. Tampilan Stok Darah

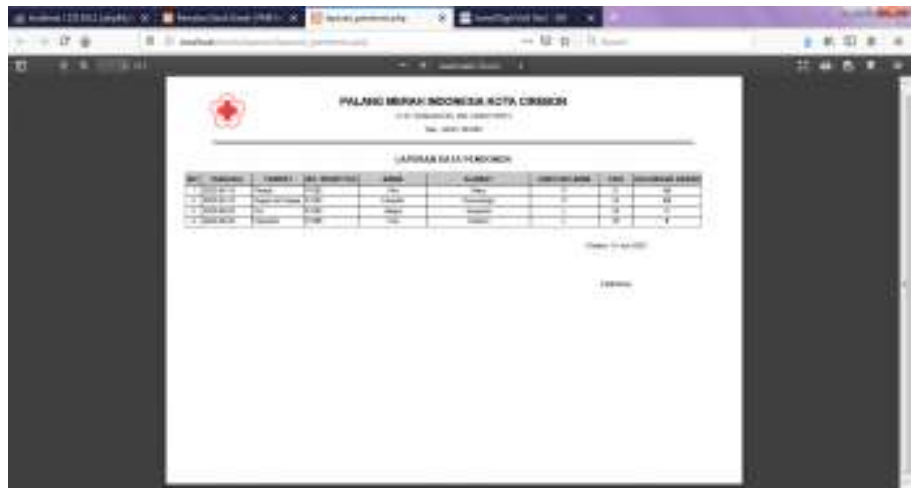

Gambar 7. Tampilan Laporan Data Pendonor 


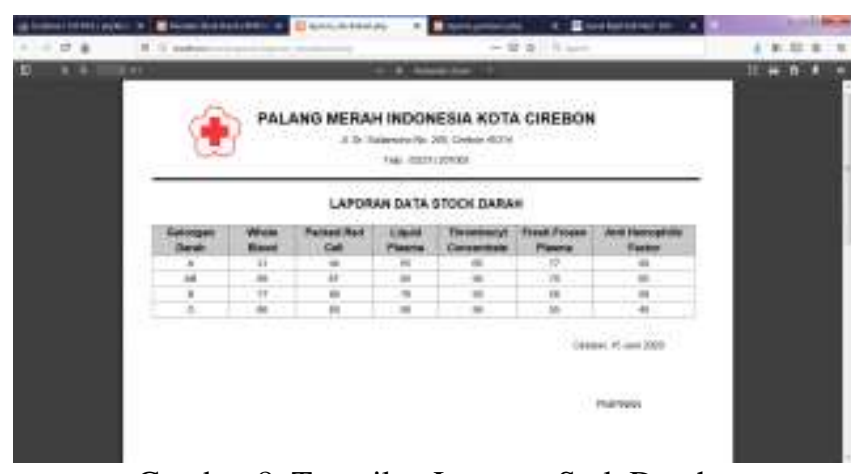

Gambar 8. Tampilan Laporan Stok Darah

\section{KESIMPULAN (Times New 10 Bold)}

Berdasarkan uraian diatas maka penulis dapat memberikan kesimpulan bahwa :

1. Rancangan Aplikasi Presediaan Stok Darah Menggunakan Metode Least Square berbasis komputer ini mempermudah bagian PMI dalam mengantisipasi terjadinya kekurangan persediaan darah pada periode selanjutnya.

2. Aplikasi Prediksi Persediaan Stok Darah Pada Palang Merah Indonesia dirancang menggunakan bahasa pemrograman PHP, database MySql yang dapat digunakan oleh UTD PMI Kota Cirebon untuk mempermudah petugas dalam mengelola permintaan kantong darah dan pembuatan laporan.

3. Faktor atau parameter yang mempengaruhi jumlah permintaan produk darah yaitu lingkungan, wabah penyakit dan perbedaan daya tahan tubuh tiap golongan darah. Selain itu jenis produk darah juga memiliki jumlah permintaan yang berbeda bergantung dengan tingkat kebutuhan darah untuk kesehatan.

\section{Daftar Pustaka}

[1] Magdalena, L., \& Mulyasari, H. Rancangan Sistem Informasi PMI Dengan Mengintegrasikan Data Pendonor dan Stok Darah Antar Cabang PMI Di Wilayah III Cirebon,2018.

[2] Sidik, Betha. Pemrograman Web dengan PHP 7, Bandung: Informatika, 2017.

[3] Sugiatno, C. A., \& Zundi, T. M. Rancang Bangun Aplikasi Donor Darah Berbasis Mobile di PMI Kabupaten Bandung. Jurnal Ilmiah Manajemen Informatika Dan Komputer, 1(1), 2017.

[4] Abdurrofi, R \& Magdalena, K. Aplikasi Untuk Optimasi Persediaan Bahan Baku Menggunakan Model Economic Order Quantity (EOQ) Pada Pabrik Tahu Di Jawa Barat, Seminar Nasional Teknologi Informasi dan Multimedia, STMIK AMIKOM, Yogyakarta. S, 2016.

[5] Hariri, F. R. Metode Least Square Untuk Prediksi Penjualan Sari Kedelai Rosi. Simetris: Jurnal Teknik
Mesin, Elektro dan Ilmu Komputer, 7(2), 731-736, 2016.

[6] SAPUTRI, N. J. Sistem Prediksi Persediaan Darah Di Pmi Kab. Gresik Dengan Metode Least Square (Doctoral dissertation, Universitas Muhammadiyah Gresik), 2016.

[7] M. Sidi, Mustaqbal., Firdaus, Roeri Fajri., \& Rahmadi, Hendra. "Pengujian Aplikasi Menggunakan Black Box Testing Boundary Value Analysis (Studi Kasus : Aplikasi Prediksi Kelulusan SNMPTN), dalam Jurnal Ilmiah Teknologi Informasi Terapan Volume I. No 3. 10 Agustus 2015. ISSN : 2407 - 3911. hlm.4. Diakses tanggal 18 Juli 2017, 2015.

[8] N. Ekawati, "Prediction of Poor Inhabitant Number Using Least Square and Moving Average Method," TELKOMNIKA, vol. 16, no. 2, pp. 369-376, 2015.

[9] Palang Merah Indonesia, -Tentang Palang Merah Indonesia (PMI), 2015.

[10] Herdianto, R., Kamar, A., \& Syofyan, E. R. Pemanfaatan Informasi Topografi dan Indeks Vegetasi untuk Studi Dinamika Proses Hidrologi Daerah Aliran Sungai (The Use of Topographic Information and Vegetation Index for Study of the Dynamics of Hydrological Processes of Catchment Area). POLI REKAYASA, 8(2), 47-54, 2013.

[11] Nahdiyan, S. Peranan Sistem Informasi Akuntansi Persediaan Peralatan Medis Dalam Menunjang Efektivitas Kerja Karyawan Unit Donor Darah Pmi (Studi Kasus Pada Unit Donor Darah Palang Merah Indonesia Kota Bandung) (Doctoral dissertation, Universitas Widyatama), 2012.

[12] Kusrini Dan Emha Taufiq Luthfi, "ALGORITMA DATA MINING", PENERBIT ANDI, 2009.

[13] Pramudiono, I. (2006). Apa itu data mining. Penerbit Andi, Yogyakarta.

[14] Nawawi. Manajemen Sumber Daya Manusia Untuk Bisnis Yang Kompetitif, Yogyakarta: Gadjah Mada University Press, 2003.

[15] Jogiyanto HM., Analisis dan Disain Informasi: Pendekatan Terstruktur Teori dan Praktek Aplikasi Bisnis, Andi Offset, Yogyakarta: 1999. 